\title{
Research on Strategies and Measures of Innovation and Entrepreneurship of College Students Promoted by Communist Youth League-Taking Guangxi University of Finance and Economics as an Example
}

\author{
Lian'gui Wei ${ }^{1, \text { a }}$ \\ ${ }^{1}$ Guangxi University of Finance and Economics, Nanning, 530003, China \\ ${ }^{\mathrm{a}}$ email
}

Keywords: Communist youth league, Promotion, Innovation and entrepreneurship of college students, Strategic measures

\begin{abstract}
Based on the practice of the Communist Youth League of Guangxi University of Finance and Economics and combined with the advantages of the Communist Youth League organizations, this paper expounds the problems existing in the process of the innovation and entrepreneurship of the college students promoted by Communist Youth League. On the basis of the analysis and study of these problems, the paper puts forward the strategic measures for the Communist Youth League to deepen the innovation and entrepreneurship for college students.
\end{abstract}

\section{Main Advantages: Determined by Basic Functions of Communist Youth League in Colleges}

As an important organization of school and the young students most closely linked, the Communist Youth League in the deepening service innovation and entrepreneurship students, the new requirement is the new situation gives the organization, but also the key areas of new period to create a new situation, do the work of the Communist Youth league. The four basic functions of the Communist Youth League organization, guidance, service and rights protection decide that it has its own advantages in deepening the service of College Students' innovation and entrepreneurship:

Organization Advantage: Complete Network System of Organization. The Communist Youth League school classes, and has to grade two grade school complete four organization network system, from school to grade two of Youth League, the Youth League to Grade Class League, each level is relatively perfect and self system, a clear organizational structure, strict and orderly, wide coverage; has extensive contacts with the youth organization network, direct student associations and other student organizations, most closely related to the students, to understand and grasp their ideological trends and practical demands.

Resource Advantage: Abundant Social Resources. The Communist Youth League organizations have rich social resources and human resources, it can use their special identity and social all walks of life to establish extensive communication and liaison, play good relations, grasp and open the business aspects of social resources, build innovation platform and information platform; can develop social practice, voluntary service and other activities, off campus training base, science and technology innovation practice base practice and actively build cooperation outside, provide many convenient services for college students entrepreneurship and innovation.

Carrier Advantage: Outstanding Work Carrier. As the most closely linked with the college students and the most timely department for the students' actual demands, the advantages of the Communist Youth League organizations are more prominent. Relying on the "three rural areas of" social practice, Challenge Cup race series, volunteer service plan of science and technology, culture and Art Festival, community cultural festival and dormitory culture festival carrier, and guide students to establish the correct concept of entrepreneurship, innovation concept, cultivate their practical ability of innovation and entrepreneurship, innovation and entrepreneurship to enhance their core competitiveness. 


\section{Actual Dilemmas: Thinking of Innovation and Entrepreneurship of College Students Promoted by Communist Youth League}

College Students' innovation and entrepreneurship is a course of action, it is to have a sense of innovation and Entrepreneurship from the complete experience of innovation and entrepreneurship awareness, awareness of innovation and entrepreneurship, innovation and entrepreneurship, the implementation achieved innovation success "four stages. In the current "popular entrepreneurship, multi innovation" era of upsurge, the Communist Youth League organizations around the country have taken various measures to promote and serve college students innovation and entrepreneurship, and received good results. However, in the various stages of deepening college students' innovation and entrepreneurship, the functional advantages of the Communist Youth League organizations in universities have not yet been fully exploited. To be specific:

Stage from Consciousness to Implementation of Innovation and Entrepreneurship. Although the construction of Guangxi University of Finance and Economics campus and the campus of the Communist Youth League College Business Park, but due to the self financing and the function of the limit, only for admission into the incubator project team to provide electricity, network, space and basic office furniture and equipment service and convenience, it is difficult to support the project funds after incubation park..

Stage from Implementation to Initial Results of Innovation and Entrepreneurship. The Communist Youth League organization itself has a higher level of theory, but the level of technical guidance is limited. It has great limitations on the technical service areas and levels of College Students' innovation and entrepreneurship. For example, the Communist Youth League of Guangxi University of Finance and Economics, due to its limited professional characteristics and limited technical level, can provide technical services for college students' innovative entrepreneurs only in terms of economy and management.

Stage from Initial Results to Success of Innovation and Entrepreneurship. The establishment of the Communist Youth League Committee of the Guangxi University of Finance and Economics "entrepreneurial innovation service center", to provide specialized services for students' innovation and entrepreneurship practice, but because of the center member for students and by the knowledge level, play in innovation and entrepreneurship practice rescue work on the role is very limited, resulting in the failure of aid for innovation and entrepreneurship the service is obviously insufficient. The main reason why the Communist Youth League organizations in deepening the innovation and Entrepreneurship of college students lies in the failure to maximize their own responsibility advantages.

\section{Strategic Measures: "Integration" Research of Innovation and Entrepreneurship of College Students Promoted by Communist Youth League}

Based on the functional advantages of the Communist Youth League in recent years, relying on the Guangxi University of Finance and Economics Youth League in deepening the creation and innovation of college students work in practice and work experience, to deepen the creation and innovation of college students in the current Communist Youth League work in the face of "dilemma", put forward to deepen the Communist Youth League college students' innovation and entrepreneurship three "integration" strategy.

Integration of Organization Structure. Organizational platform is an important support for deepening the innovation and Entrepreneurship of College students. The Communist Youth League should strive for the support of the Party leadership, the integration of local governments, enterprises and other organizations and group resources, construction of College Students' innovation and entrepreneurship service multi-level integration to create a unified pattern, deepening innovation and entrepreneurship students work. Such as Guangxi University of Finance and Economics in the district in the establishment of independent operation of the innovation and entrepreneurship education, entrepreneurship and innovation service center set up by the students, the school committee and the 
science department, office of academic affairs, experimental center to undertake business guidance functions work to deepen college students' innovation and Entrepreneurship services to provide organization guarantee. Through the creation and innovation of college students to build integrated service network, realize the deepening of innovation and entrepreneurship students work positions, personnel, funds and system, push forward the innovation of implementing entrepreneurship policy, innovation and entrepreneurship training popularization, effective sharing of innovation and entrepreneurship, innovation and entrepreneurship information reasonable allocation of funds, ensure the durability and effectiveness of the Communist Youth League to deepen the innovation of college students.

Integration of Service System. On the stage of innovation and entrepreneurship students all needed to further establish and improve the information base, training, and service projects and other types of College Students' innovation and entrepreneurship projects, systematic innovation and entrepreneurship students "service chain, improve the organization of the Communist Youth League to deepen the service ability and the level of students' innovation and entrepreneurship.

Strengthening the construction of information service platform for college students' innovation and entrepreneurship. According to the current situation of the development of the information age, the Communist Youth League should speed up the construction of information network infrastructure, strengthen the construction of talent team, help the students to analyze the situation at home and abroad, integrated analysis of a large number of various types of information resources, and guide them to establish a correct concept of innovation and entrepreneurship; optimization of youth organizations at various levels such as online portals, continued to publish the Communist Youth League organizations at all levels to promote the work of dynamic college students' innovation and entrepreneurship. We regularly publish the country to promote the college students' innovation and entrepreneurship policy, the latest update employment information, recommend innovation and industry project, borrow the young students loved the new media, the popularity of innovation and entrepreneurship information service.

Strengthen the construction of innovative education platform for college students. The Communist Youth League organizations according to the classification, hierarchical implementation, and to ensure the effectiveness of training mode, adhere to the combination of market demand and the characteristics of the students and strengthen the principle of relevant government departments, employers, social forces contact and coordination with government related training programs and the school fees, relying on Entrepreneurship and entrepreneurship service alliance positions continuously to strengthen college students' innovation and entrepreneurship education and training platform construction. Guangxi University of Finance and Economics Communist Youth League to integrate all resources, the mature entrepreneurship training program into the school, in cooperation with the Nanning youth occupation skill training center and other training institutions, holding SYB (or start your business) training and strive to build college students innovation and entrepreneurship education and training brand activities.

Promoting the construction of innovative practice platform for college students. Build innovation and entrepreneurship training base for college students and practice platform, is effective to enhance students innovative ability and level and the effective way. The construction of off campus practice base for the students of entrepreneurship and innovation, provide more opportunities to practice and innovation platform for the wide wealth of young college students.

Improving the service of innovative project for college students. The implementation of the project is the key link in the success of College Students' innovation and entrepreneurship. The Communist Youth League organizations to improve the services of college students in the implementation of innovation and entrepreneurship in the process of project: building innovation project library, organize project fair, promote market prospects for good projects, provide project docking services for the majority of students; to carry out the evaluation and demonstration project of innovation and entrepreneurship, to help the students to choose the appropriate project. The advantages and resources of Guangxi University of Finance and Economics students' innovative entrepreneurial team on behalf of the Communist Youth League school based on the typical "new 
property" in the team of teachers and students, social enterprises have, combined in perfect innovation and entrepreneurship services together to help students project.

In addition, the Communist Youth League organization should strengthen the reward for college students in innovation and entrepreneurship, unify the standards of reward, enlarge the scope of rewards and optimize the reward methods. According to the diversity of the needs of different innovative entrepreneurs, we can adopt diversified forms of incentives such as human, financial, material and technological, and encourage the majority of students to participate in innovation and entrepreneurship practice. At the same time to communicate actively with the people's insurance, social security and other departments, in consultation assistance, provide relief protection fund for innovation and entrepreneurship losers.

Integration of Work Mechanism. Working mechanism is an important guarantee for deepening standardization and normalization development of College Students' innovation and entrepreneurship. Communist Youth League organizations at all levels should combine their own reality, efforts to improve the integration of relevant working mechanism from the four aspects of leadership, communication and collaboration, information sharing, target management, provide a strong protection mechanism for deepening the work continued to promote college students' innovation and entrepreneurship. Communist Youth League organizations at all levels should be combined with the actual situation, will deepen the creation and innovation of college students work goal, work to refine the decomposition, to ensure the full implementation of the deployment at the grassroots level, forming a good situation on all fronts, Communist Youth League organizations at all levels of their duties, and jointly promote the go hand in hand.

Deepening the innovation and Entrepreneurship of college students is a long-term systematic project. The Communist Youth League organizations at all levels should adhere to the people-centered education, renew the educational concept, innovate the work mechanism, give full play to its advantages, the integration of all resources, and constantly improve the service system of innovation and entrepreneurship, cultivating students' innovative entrepreneurship, innovation and entrepreneurship to improve their quality and ability, adapt to the current "public record" under the new requirements of the times of social work of the Communist Youth League.

\section{Acknowledgements}

This research is the results of the Research Subject of Theory and Practice of Ideological and Political Education of College Students in Guangxi in 2015 (Grant No. 2015LSZ019) led by Liangui Wei and named "Research on Strategies and Measures of Innovation and Entrepreneurship of College Students Promoted by Communist Youth League - Taking Guangxi University of Finance and Economics as an Example".

\section{References}

[1] Zheng Yang, The Research on the Advantages and the Path of the College Students' Entrepreneurship in College League Organizations [J]. Higher Education Forum, 2015(7): 114-116.

[2] Zhao Jianli, Fang Guozhong, The Studies on College Students Entrepreneurship Education Mode of "Five in One" Under the Perspective of the Communist Youth League [J]. Heilongjiang Researchers on Higher Education, 2015(5): 89-91.

[3] Jiang Yan, Song Ruimei, Fan Lisan, The Function of the Communist Youth League in College Students’ Entrepreneurship Education [J]. Meitan Higher Education, 2015, 33(4): 39-42.

[4] Du Yinghua, Li Ziming, Effective Path Study of the Communist Youth League Organizations Promoting Graduates' Entrepreneurship [J]. The Guide of Science \& Education, 2015(6): 81-82. 